\title{
Distribution of Vernalization and Photoperiod Genes (Vrn-A1, Vrn-B1, Vrn-D1, Vrn-B3, Ppd-D1) in Turkish Bread Wheat Cultivars and Landraces
}

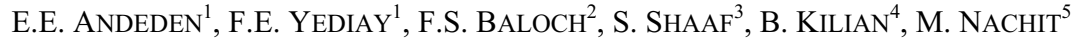 \\ and $\mathrm{H}$. ÖZKAN ${ }^{1,2 *}$ \\ ${ }^{1}$ Department of Biotechnology, Institute of Basic and Applied Sciences, University of Çukurova, \\ 01330 Adana, Turkey \\ ${ }^{2}$ Department of Field Crops, Faculty of Agriculture, University of Çukurova, 01330 Adana, Turkey \\ ${ }^{3}$ Department of Agronomy and Plant Breeding, University of Tehran, Tehran, Iran \\ ${ }^{4}$ Leibniz Institute of Plant Genetics and Crop Plant Research (IPK), Genebank/ Genome Diversity, \\ Corrensstrasse 3, D-06466 Gatersleben, Germany \\ ${ }^{5}$ ICARDA, P.O. Box 5466, Aleppo, Syria
}

(Received 8 August 2010; accepted 5 October 2010;

Communicated by A. Aniol)

\begin{abstract}
Vernalization and photoperiod response genes play a significant role in the geographical adaptation, agronomic performance and yield potential of crops. Therefore, understanding the distribution pattern and allelic diversity for vernalization and photoperiod genes are important in any wheat breeding program. In this study, we screened 63 bread wheat cultivars and 7 bread wheat landraces from Turkey for photoperiod (Ppd-D1) and vernalization genes (Vrn-A1, Vrn-B1, Vrn-D1 and Vrn-B3) using diagnostic molecular markers. The photoperiod insensitive dominant allele, $P p d-D 1 a$, was present in $60 \%$ of wheat cultivars and $42 \%$ of landraces, whereas, all other genotypes carried the photoperiod sensitive allele $P p d-D 1 b$ as recessive allele. Twenty-four cultivars and two landraces contained recessive alleles for all four VRN loci, whereas 39 wheat cultivars and 6 landraces contained one or more dominant VRN alleles. The highest percentage of Turkish wheat cultivars contained the dominant $V r n-B 1$ allele followed by $V r n-D 1$ and $V r n-A 1$. Information for vernalization and photoperiod alleles in Turkish germplasm will facilitate the planning and implementation of molecular markers in wheat breeding programs. This information will be helpful to develop elite wheat cultivars carrying suitable vernalization and photoperiod alleles with higher grain yield potential and better quality suitable for different production environments through marker assisted selection.
\end{abstract}

Keywords: vernalization, photoperiod, $P p d-D 1, V r n$, molecular markers, bread wheat, Triticum, Turkey

\footnotetext{
* Corresponding author; E-mail: hozkan@mail.cu.edu.tr
} 


\section{Introduction}

Bread wheat was originated in the Fertile Crescent about 8000 years ago. Today this crop is widely grown in various geographical regions ranging from $67^{\circ}$ North to $45^{\circ}$ South (Kilian et al. 2009). For adaptation to such diverse areas, a wide range of genetic variations at specific loci is indispensable. Among these, the regulation of flowering time is most important criterion for adaptation to such a wide range of growing conditions. Growth and developmental phases (i.e. tillering, stem elongation, heading, anthesis and maturity) of wheat are primarily determined by vernalization genes (Vrn), genes that control the photoperiod response (Ppd) and earliness per se genes (Eps) (Dubcovsky et al. 1998). The adaptability of bread wheat to a wide range of environments has been favored by allelic diversity in genes regulating growth habit ( $V r n$ genes) and photoperiod response ( $P p d$ genes) (Distelfeld et al. 2009). Differences in Vrn genes divide wheat into spring, winter and facultative types, whereas differences in the Ppd genes divide the germplasm into day length-sensitive and day length-insensitive classes.

Increasing knowledge about the genetics of growth habit will contribute to a better understanding about the adaptation of wheat and promote their breeding for specific environments (Goncharov 2003). In bread wheat, vernalization requirement is primarily controlled by alleles at three orthologous loci, $V r n-A 1, V r n-B 1$ and $V r n-D 1$ (collectively these three alleles are designated as ' $V r n-1$ ' loci, Santra et al. 2009), which are located on the long arms of chromosomes 5A, 5B and 5D, respectively (Yan et al. 2003; 2004; Zhang et al. 2008). Santra et al. (2009) reported that the presence of a dominant $V r n-1$ allele in any genome confers spring growth habit, whereas the presence of recessive alleles in the homozygous state across $V r n-1$ loci confers winter growth habit. According to Santra et al. (2009), $V r n-A 1$ is most effect allele providing complete insensitivity to vernalization, and is epistatic to $V r n-B 1$ and $V r n-D 1$, whereas, $V r n-B 1$ and $V r n-D 1$ are slightly vernalization sensitive alleles, having small residual vernalization requirements. In addition to these alleles, other groups of vernalization genes have been detected in wheat such as the Vrn-2 series located on chromosomes 4B, 4D and 5A; Vrn-B3 (located on chromosome 7BS) and Vrn-D5 (located on chromosome 5D) (Goncharov 2003; Yan et al. 2006; Santra et al. 2009).

In recent years, the $V r n-1$ alleles were cloned, sequenced and, diagnostic molecular marker for Vrn1 alleles have been developed (Yan et al. 2003, 2004; Fu et al. 2005). Diagnostic molecular markers provide a unique opportunity to screen large collections of wheat germplasm for allelic diversity, because detection of vernalization and photoperiod genes by traditional genetic methods is time consuming. Yan et al. (2003, 2004) reported that different dominant $V r n-A 1$ alleles have been found as follow (i) $V r n-A 1 a$ resulted due duplication in the promoter region, (ii) $V r n-A 1 b$ developed due to deletion in the promoter region and (iii) $V r n-A 1 c$ developed due to large deletion in the Intron1. Zhang et al. (2008) studied allelic variation at the vernalization genes $V r n-A 1, V r n-B 1, V r n-D 1$ and $V r n-B 3$ in Chinese wheat cultivars using diagnostic marker developed by Fu et al. (2005) and Yan et al. (2004). These authors reported that the dominant $V r n-D 1$ allele showed highest frequency in Chinese wheat cultivars $(37.8 \%)$, followed by the dominant $V r n-A 1, V r n-B 1$ 
and $V r n-B 3$ alleles. Ninety-two winter cultivars carried recessive alleles for all four vernalization loci, whereas 172 spring genotypes contained at least one dominant $\mathrm{Vrn}$ allele.

Wheat are classified as 'photoperiod sensitive', which require long days for flowering, or 'photoperiod insensitive', which flower under long or short day environments (Dyck et al. 2004). Scarth and Law (1984) reported that three genes control photoperiod response in wheat including $P p d-D 1$ located on the long arm of chromosome 2D, $P p d-B 1$ on the short arm of $2 \mathrm{~B}$ and $P p d-A 1$ located on the long arm of $2 \mathrm{~A}$. Insensitivity of wheat to day length is conferred by dominant alleles represented as $P p d-D 1 a, P p d-B 1 a$ and $P p d-A 1 a$, whereas recessive forms of these alleles $(P p d-D 1 b, P p d-B 1 b$ and $P p d-A 1 b)$ result in photoperiod sensitivity. Worland (1998) reported that the potency of the group 2 photoperiod genes for insensitivity has been ranked in the order $P p d-D 1>P p d-B 1>P p d-A 1$. Recently, significant progress has been achieved in molecular characterization of photoperiod responsive genes in bread wheat. Beales et al. (2007) developed diagnostic markers for Ppd-D1 that enables to detect allelic variation within $P p d-D 1$ loci. Using these DNA markers, Yang et al. (2009) studied the distribution of the photoperiod insensitive allele Ppd-Dla in Chinese wheat cultivars. They screened 926 Chinese wheat landraces and improved cultivars collected from nine wheat growing zones for $P p d-D 1$ locus using diagnostic markers. They observed that $66 \%$ of Chinese wheat landraces and improved varieties carried photoperiod-insensitive allele.

Modern breeding in Turkey started in 1925 with the goal to select well-adapted lines from local landraces for wheat improvement. In 1967, the national wheat release and training project was established with contribution of international organizations, by introducing several cultivars from foreign countries (Braun et al. 2001). The national wheat breeding program, meanwhile, developed more than 100 wheat cultivars, most of which has significant impact on the economy of country. However, Turkish wheat cultivars released since 1935, have not been screened systematically for vernalization and photoperiod alleles. Therefore, we aimed to characterize a collection of Turkish bread wheat cultivars and landraces for allelic variations at four vernalization and one photoperiod gene in order to select parental lines for marker assisted breeding programs.

\section{Materials and Methods}

\section{Plant material}

In total, seventy bread wheat genotypes, including sixty-three bread wheat cultivars (Triticum aestivum L.) most of them released in Turkey during the last 70 years and seven bread wheat landraces from Turkey were included in this study (Table 1). Three wheat genotypes, namely Chinese Spring (vrn-Al), Thatcher (Vrn-Ala) and Hope (Vrn-B3) were used as controls, in order to confirm the presence or absence of specific vernalization alleles. 


\section{DNA extraction and PCR analysis for vernalization and photoperiod alleles}

Three plants of each cultivar and landrace were grown in the greenhouse. Young leaf samples were collected from 10 days old seedlings, frozen in liquid nitrogen and stored at $-80^{\circ} \mathrm{C}$ until use. Genomic DNA was then extracted by the CTAB method (Doyle and Doyle 1987) with minor modifications (Ozkan et al. 2005). For the characterization of vernalization alleles, eleven diagnostic markers were used to detect dominant or recessive alleles of $V r n-A 1, V r n-B 1, V r n-D 1$ and $V r n-B 3$ (Yan et al. 2004; Fu et al. 2005). In order to identify dominant and recessive photoperiod alleles, two primer combinations as described by Yang et al. (2009), were used. All PCR amplifications were performed in a gradient thermal cycler (Eppendorf, Hamburg, Germany). Details about PCR based markers for vernalization and photoperiod genes, their sequences and amplification conditions are briefly presented in Table 2 . All amplification reactions were carried out in a $25 \mu 1$ volume containing $75 \mathrm{mM}$ Tris-HCl, $\mathrm{pH} 8.8,20 \mathrm{mM}\left(\mathrm{NH}_{4}\right)_{2} \mathrm{SO}_{4}, 2.0 \mathrm{mM} \mathrm{MgCl}_{2}, 0.1 \%$ Tween 20, $0.2 \mu \mathrm{M}$ primer pair, $100 \mu \mathrm{M}$ each of dATP, dGTP, dCTP and dTTP, 1 unit of Taq DNA polymerase and $20 \mathrm{ng}$ of genomic DNA. All amplified products were analyzed by gel electrophoresis on $2 \%$ agarose gels in $0.5 \times$ TBE buffer, stained with ethidium bromide and photographed under ultraviolet light. The experiments were replicated three times in order to confirm the reproducibility of results.

\section{Results}

\section{Allelic frequencies at Ppd-D1}

To study allelic diversity at $P p d-D 1$ locus, two specific primer combinations were used (Yang et al. 2009; Table 2). Out of 70 cultivars and landraces, 25 cultivars and 4 landraces yielded a 418 bp PCR fragment, indicating the presence of the photoperiod sensitive $P p d-D 1 b$ allele, and 38 cultivars and 3 landraces gave a $290 \mathrm{bp}$ fragment, indicative of the photoperiod-insensitive $P p d-D 1 a$ allele. The overall frequency of the dominant $P p d-D 1 a$ allele in Turkish cultivars and landraces were $59 \%$, with frequencies of $43 \%$ and $60 \%$ in landraces and cultivars, respectively.

\section{Allelic frequencies at $\mathrm{Vrn}-\mathrm{A} 1, \mathrm{Vrn}-\mathrm{B} 1, \mathrm{Vrn}-\mathrm{D} 1$ and $\mathrm{Vrn}-\mathrm{B} 3$}

Diagnostic markers VRN1AF and VRB1-INT1R as described by Yan et al. (2004) were used in all Turkish bread wheat cultivars and landraces, in order to identify the variation in the promoter region of the dominant spring allele Vrn-Al (Table 2). We found that only seven cultivars and one landrace yielded two fragments similar to Thatcher used as control (970 bp and $870 \mathrm{bp}$ ). This indicated that these genotypes carry the dominant Vrn-Ala allele at the $V r n-A 1$ locus. A 720 bp PCR product was observed only in two cultivars, namely Ak-702 and Yayla, which represents the presence of $V r n-A 1 b$ allele (Table 2). The remaining 60 cultivars and landraces including the control Chinese Spring gave a $740 \mathrm{bp}$ PCR product, which indicated that these genotypes carry either the dominant $V r n-A 1 c$ allele or the recessive $v r n-A 1$ allele, as reported by Zhang et al. (2008). In order to differentiate between these two alleles; we used two primers pairs Intr1/A/F2-Intr1/A/R3 and 
Table 1. Allelic variation at Vrn-A1, Vrn-B1, Vrn-D1, Vrn-B3 and Ppd-D loci in Turkish bread wheat cultivars and landraces

\begin{tabular}{|c|c|c|c|c|c|c|c|}
\hline Cultivar & $\begin{array}{l}\text { Registration } \\
\text { date }\end{array}$ & $V r n-A 1$ & $V r n-B 1$ & $V r n-D 1$ & $V r n-B 3$ & $\begin{array}{c}\text { Ppd-Dla } \\
\text { (insensitive) }\end{array}$ & $\begin{array}{l}\text { Ppd-Dlb } \\
\text { (sensitive) }\end{array}$ \\
\hline Ak-702 & 1935 & $\mathrm{Db}$ & $\mathrm{D}^{*}$ & $\mathrm{r}$ & $\mathrm{r}$ & - & + \\
\hline Yayla & 1935 & $\mathrm{Db}$ & $\mathrm{r}$ & $\mathrm{r}$ & $\mathrm{r}$ & + & - \\
\hline Sertak & 1936 & $\mathrm{r}^{* *}$ & $\mathrm{D}$ & $\mathrm{r}$ & $\mathrm{r}$ & - & + \\
\hline Sivas-111/33 & 1937 & $\mathrm{r}$ & $\mathrm{D}$ & $\mathrm{r}$ & $\mathrm{r}$ & - & + \\
\hline 4.11 & 1952 & $\mathrm{r}$ & $\mathrm{D}$ & $\mathrm{r}$ & $\mathrm{r}$ & - & + \\
\hline P86 & 1966 & $\mathrm{r}$ & $\mathrm{D}$ & $\mathrm{D}$ & $\mathrm{r}$ & - & + \\
\hline P88 & 1966 & $\mathrm{r}$ & $\mathrm{D}$ & $\mathrm{D}$ & $\mathrm{r}$ & - & + \\
\hline Bezostaja-1 & 1968 & $\mathrm{r}$ & $\mathrm{r}$ & $\mathrm{r}$ & $\mathrm{r}$ & - & + \\
\hline Yektay & 1967 & $\mathrm{r}$ & $\mathrm{D}$ & $\mathrm{r}$ & $\mathrm{r}$ & - & + \\
\hline Orso-2 & 1970 & $\mathrm{r}$ & $\mathrm{r}$ & $\mathrm{D}$ & $\mathrm{r}$ & + & - \\
\hline Bolal & 1970 & $\mathrm{r}$ & $\mathrm{r}$ & $\mathrm{r}$ & $\mathrm{r}$ & + & - \\
\hline Kıraç-66 & 1970 & $\mathrm{r}$ & $\mathrm{r}$ & $\mathrm{r}$ & $\mathrm{r}$ & - & + \\
\hline Cumhuriyet-75 & 1976 & $\mathrm{r}$ & $\mathrm{D}$ & $\mathrm{r}$ & $\mathrm{r}$ & + & - \\
\hline Kirkpinar & 1979 & $\mathrm{Da}$ & $\mathrm{r}$ & $\mathrm{r}$ & $\mathrm{r}$ & - & + \\
\hline Gerek-79 & 1979 & $\mathrm{r}$ & $\mathrm{r}$ & $\mathrm{r}$ & $\mathrm{r}$ & + & - \\
\hline Atay-85 & 1985 & $\mathrm{r}$ & $\mathrm{D}$ & $\mathrm{r}$ & $\mathrm{r}$ & - & + \\
\hline Çukurova- 86 & 1986 & $\mathrm{Da}$ & $\mathrm{D}$ & $\mathrm{r}$ & $\mathrm{r}$ & + & - \\
\hline Doğu- 88 & 1990 & $\mathrm{r}$ & $\mathrm{r}$ & $\mathrm{r}$ & $\mathrm{r}$ & - & + \\
\hline Gün-91 & 1991 & $\mathrm{r}$ & $\mathrm{D}$ & $\mathrm{r}$ & $\mathrm{r}$ & + & - \\
\hline Seri-82 & 1991 & $\mathrm{r}$ & $\mathrm{D}$ & $\mathrm{D}$ & $\mathrm{r}$ & + & - \\
\hline Doğankent-1 & 1992 & $\mathrm{Da}$ & $\mathrm{D}$ & $\mathrm{D}$ & $\mathrm{r}$ & + & - \\
\hline Kutluk-94 & 1994 & $\mathrm{r}$ & $\mathrm{r}$ & $\mathrm{D}$ & $\mathrm{r}$ & - & + \\
\hline Dağdaş-94 & 1994 & $\mathrm{r}$ & $\mathrm{r}$ & $\mathrm{r}$ & $\mathrm{r}$ & - & + \\
\hline Kirg1z-95 & 1995 & $\mathrm{r}$ & $\mathrm{r}$ & $\mathrm{r}$ & $\mathrm{r}$ & + & - \\
\hline Seyhan-95 & 1995 & $\mathrm{r}$ & $\mathrm{D}$ & $\mathrm{D}$ & $\mathrm{r}$ & + & - \\
\hline İkizce-96 & 1996 & $\mathrm{r}$ & $\mathrm{r}$ & $\mathrm{r}$ & $\mathrm{r}$ & + & - \\
\hline Palandöken-97 & 1997 & $\mathrm{r}$ & $\mathrm{D}$ & $\mathrm{r}$ & $\mathrm{r}$ & - & + \\
\hline Süzen-97 & 1997 & $\mathrm{r}$ & $\mathrm{D}$ & $\mathrm{r}$ & $\mathrm{r}$ & - & + \\
\hline Kınac1-97 & 1997 & $\mathrm{r}$ & $\mathrm{r}$ & $\mathrm{r}$ & $\mathrm{r}$ & + & - \\
\hline Pehlivan & 1998 & $\mathrm{r}$ & $\mathrm{r}$ & $\mathrm{r}$ & $\mathrm{r}$ & + & - \\
\hline Türkmen & 1998 & $\mathrm{r}$ & $\mathrm{r}$ & $\mathrm{r}$ & $\mathrm{r}$ & + & - \\
\hline Aytın-98 & 1998 & $\mathrm{r}$ & $\mathrm{D}$ & $\mathrm{r}$ & $\mathrm{r}$ & + & - \\
\hline Ziyabey-98 & 1998 & $\mathrm{r}$ & $\mathrm{D}$ & $\mathrm{D}$ & $\mathrm{r}$ & - & + \\
\hline Gönen-98 & 1998 & $\mathrm{Da}$ & $\mathrm{D}$ & $\mathrm{r}$ & $\mathrm{r}$ & + & - \\
\hline Y1ld1z-98 & 1998 & $\mathrm{r}$ & $\mathrm{r}$ & $\mathrm{r}$ & $\mathrm{r}$ & - & + \\
\hline Göksu-99 & 1999 & $\mathrm{r}$ & $\mathrm{D}$ & $\mathrm{r}$ & $\mathrm{r}$ & - & + \\
\hline Karahan-99 & 1999 & $\mathrm{r}$ & $\mathrm{D}$ & $\mathrm{r}$ & $\mathrm{r}$ & - & + \\
\hline Yakar-99 & 1999 & $\mathrm{r}$ & $\mathrm{r}$ & $\mathrm{r}$ & $\mathrm{r}$ & - & + \\
\hline Harmankaya-99 & 1999 & $\mathrm{r}$ & $\mathrm{r}$ & $\mathrm{r}$ & $\mathrm{r}$ & - & + \\
\hline Ceyhan-99 & 1999 & $\mathrm{r}$ & $\mathrm{D}$ & $\mathrm{D}$ & $\mathrm{r}$ & + & - \\
\hline Adana-99 & 1999 & $\mathrm{r}$ & $\mathrm{D}$ & $\mathrm{D}$ & $\mathrm{r}$ & + & - \\
\hline Genç-99 & 1999 & $\mathrm{r}$ & $\mathrm{D}$ & $\mathrm{D}$ & $\mathrm{r}$ & + & - \\
\hline Golia & 1999 & $\mathrm{r}$ & $\mathrm{r}$ & $\mathrm{D}$ & $\mathrm{r}$ & + & - \\
\hline Çetinel-2000 & 2000 & $\mathrm{r}$ & $\mathrm{r}$ & $\mathrm{r}$ & $\mathrm{r}$ & - & + \\
\hline Aksel-2000 & 2000 & $\mathrm{r}$ & $\mathrm{r}$ & $\mathrm{r}$ & $\mathrm{r}$ & - & + \\
\hline Demir-2000 & 2000 & $\mathrm{r}$ & $\mathrm{D}$ & $\mathrm{r}$ & $\mathrm{r}$ & + & - \\
\hline Bayraktar-2000 & 2000 & $\mathrm{r}$ & $\mathrm{r}$ & $\mathrm{r}$ & $\mathrm{r}$ & + & - \\
\hline
\end{tabular}

Cereal Research Communications 39, 2011 


\begin{tabular}{|c|c|c|c|c|c|c|c|}
\hline Cultivar & $\begin{array}{l}\text { Registration } \\
\text { date }\end{array}$ & Vrn-A1 & Vrn-B1 & Vrn-D1 & Vrn-B3 & $\begin{array}{c}P p d-D 1 a \\
\text { (insensitive) }\end{array}$ & $\begin{array}{l}P p d-D 1 b \\
\text { (sensitive) }\end{array}$ \\
\hline Balattila & 2000 & $\mathrm{r}$ & $\mathrm{D}$ & $\mathrm{D}$ & $\mathrm{r}$ & - & + \\
\hline Tahirova-2000 & 2000 & $\mathrm{Da}$ & $\mathrm{r}$ & $\mathrm{D}$ & $\mathrm{r}$ & + & - \\
\hline Pandas & 2001 & $\mathrm{r}$ & $\mathrm{r}$ & $\mathrm{D}$ & $\mathrm{r}$ & + & - \\
\hline İzgi-2001 & 2001 & $\mathrm{r}$ & $\mathrm{r}$ & $\mathrm{D}$ & $\mathrm{r}$ & + & - \\
\hline Sönmez-2001 & 2001 & $\mathrm{r}$ & $\mathrm{D}$ & $\mathrm{r}$ & $\mathrm{r}$ & + & - \\
\hline Alparslan & 2001 & $\mathrm{r}$ & $r$ & $\mathrm{r}$ & r & + & - \\
\hline Nenehatun & 2001 & $\mathrm{r}$ & $\mathrm{r}$ & $\mathrm{r}$ & $\mathrm{r}$ & + & - \\
\hline Nurkent & 2001 & $\mathrm{Da}$ & $\mathrm{D}$ & $\mathrm{r}$ & $\mathrm{r}$ & + & - \\
\hline Zencirci-2002 & 2002 & $\mathrm{r}$ & $\mathrm{R}$ & $\mathrm{r}$ & $\mathrm{r}$ & + & - \\
\hline Yüreǧir-89 & 2002 & $\mathrm{Da}$ & $\mathrm{D}$ & $\mathrm{r}$ & $\mathrm{r}$ & + & - \\
\hline Dariel & 2002 & $\mathrm{r}$ & $\mathrm{D}$ & $\mathrm{D}$ & $\mathrm{r}$ & + & - \\
\hline Tosunbey & 2004 & $\mathrm{r}$ & $\mathrm{D}$ & $\mathrm{r}$ & $\mathrm{r}$ & + & - \\
\hline Gelibolu & 2005 & $\mathrm{r}$ & $\mathrm{r}$ & $\mathrm{r}$ & $\mathrm{r}$ & + & - \\
\hline Karatopak & 2006 & $\mathrm{r}$ & $\mathrm{D}$ & $\mathrm{D}$ & $\mathrm{r}$ & + & - \\
\hline Osmaniyem & 2006 & $\mathrm{r}$ & $\mathrm{r}$ & $\mathrm{D}$ & $\mathrm{r}$ & + & - \\
\hline \multicolumn{8}{|l|}{ Landraces } \\
\hline Kirık & & $\mathrm{r}$ & $\mathrm{D}$ & $\mathrm{r}$ & $\mathrm{r}$ & - & + \\
\hline Tir & & $\mathrm{r}$ & $\mathrm{r}$ & $\mathrm{r}$ & $\mathrm{r}$ & - & + \\
\hline Aşure & & $\mathrm{Da}$ & $\mathrm{D}$ & $\mathrm{r}$ & $\mathrm{r}$ & + & - \\
\hline Koca buğday & & $\mathrm{r}$ & $\mathrm{D}$ & $\mathrm{r}$ & $\mathrm{r}$ & + & - \\
\hline Kırmızı başak & & $\mathrm{r}$ & $\mathrm{D}$ & $\mathrm{r}$ & $\mathrm{r}$ & + & - \\
\hline Akbugday & & $\mathrm{r}$ & $\mathrm{D}$ & $\mathrm{r}$ & $\mathrm{r}$ & - & + \\
\hline İngiliz Buğdayi & & $\mathrm{r}$ & $\mathrm{r}$ & $\mathrm{r}$ & $\mathrm{r}$ & - & + \\
\hline
\end{tabular}

Abbreviations: D and $\mathbf{r}$ refer to dominant and recessive allele for $V r n-A 1, V r n-B 1, V r n-D 1$ and $V r n-B 3$; Da and Db refer to $V r n-A l a$ and $V r n-A 1 b .+,-$ refer to present of dominant and recessive allele of Ppd-D1a and Ppd-D $1 b$, respectively

Intr1/C/F-Intr1/AB/R specific for Intron1 deletion (Vrn-Alc) and the recessive $v r n-A 1$ allele, respectively. We found the absence of the $V r n-A 1 c$ allele in all tested Turkish wheats and in the control 'Chinese Spring'. On the other hand, all genotypes gave 1060 PCR products, indicating that they carry the recessive $v r n-A 1$ allele.

Thirty-two bread wheat cultivars and 5 landraces including the control Chinese Spring harbor the dominant $V r n-B 1$ allele because a 712 bp band was amplified in these lines using the primer combination Intr1/B/F-Intr1/B/R3. The absence of a PCR product in the remaining wheat genotypes suggests that they carry the recessive allele. The primer combination Intr1/B/F-Intr1/B/R4 was used to confirm the presence of the recessive allele. Thirty-one bread wheat cultivars and two landraces amplified 1160 bp PCR product, showing the presence of the recessive $v r n-B 1$ allele.

Using primer pair Intr1/D/F-Intr1/D/R3, nineteen wheat cultivars generated a $1670 \mathrm{bp}$ PCR product, demonstrating that these varieties carried the dominant Vrn-D1 allele. A $991 \mathrm{bp}$ fragment was generated from 44 wheat cultivars and seven landraces using the primer pair Intr1/D/F-Intr1/D/R4, indicating the presence of the recessive $v r n-D 1$ allele. 


\begin{tabular}{|c|c|c|c|c|c|c|}
\hline Locus & Allele & Marker name & Primer pair sequence $\left(5^{\prime} \rightarrow 3^{\prime}\right)$ & Reference & PCR conditions & $\begin{array}{l}\text { PCR product size } \\
(\mathrm{bp})\end{array}$ \\
\hline \multirow[t]{9}{*}{ Vrn-A1 } & $V r n-A l a$ & VRN1AF & GAAAGGAAAAATTCTGCTCG & Yan et al. (2004), & \multirow{4}{*}{$\begin{array}{l}95^{\circ} \mathrm{C} \text { for } 3 \mathrm{~min} ; 94^{\circ} \mathrm{C} \text { for } 45 \mathrm{~s} ; \\
60^{\circ} \mathrm{C} \text { for } 60 \mathrm{~s} \text {, and } 72^{\circ} \mathrm{C} \text { for } \\
90 \mathrm{~s} \text { for } 30 \text { cycles }\end{array}$} & $970+870$ \\
\hline & $V r n-A l b$ & VRN-INT1R & GCAGGAAATCGAAATCGAAG & Zhang et al. (2008) & & 720 \\
\hline & $V r n-A l c$ & & & & & 740 \\
\hline & $v r n-A l$ & & & & & 740 \\
\hline & \multirow[t]{2}{*}{$V r n-A l c$} & Intr1/A/F2 & AGCCTCCACGGTTTGAAAGTAA & Fu et al. (2005), & $95^{\circ} \mathrm{C}$ for $3 \mathrm{~min} ; 94^{\circ} \mathrm{C}$ for $45 \mathrm{~s}$ & 1170 (Expected \\
\hline & & Intr1/A/R3 & AAGTAAGACAACACGAATGTGAGA & Zhang et al. (2008) & $\begin{array}{l}60^{\circ} \mathrm{C} \text { for } 60 \mathrm{~s} \text {, and } 72^{\circ} \mathrm{C} \text { for } \\
90 \mathrm{~s} \text { for } 30 \text { cycles }\end{array}$ & PCR size) \\
\hline & \multirow[t]{3}{*}{$v r n-A l$} & Intr1/C/F & GCACTCCTAAACCACTAACC & Fu et al. (2005), & $94^{\circ} \mathrm{C}$ for $4 \mathrm{~min} ; 94^{\circ} \mathrm{C}$ for $15 \mathrm{~s}$ & 1060 \\
\hline & & Intr1/AB/R & TCATCCATCATCAAGGCAAA & Zhang et al. (2008) & $65^{\circ} \mathrm{C}$ for $45 \mathrm{~s}$, and $72^{\circ} \mathrm{C}$ & \\
\hline & & & & & for $45 \mathrm{~s}$ for 30 cycles & \\
\hline \multirow[t]{6}{*}{ Vrn-B1 } & \multirow[t]{3}{*}{$V r n-B 1$} & Intr1/B/F & CAAGTGGAACGGTTAGGACA & Fu et al. (2005), & $94^{\circ} \mathrm{C}$ for $4 \mathrm{~min} ; 94^{\circ} \mathrm{C}$ for $15 \mathrm{~s}$ & 712 \\
\hline & & Intr1/B/R3 & CTCATGCCAAAAATTGAAGATGA & Zhang et al. (2008) & $65^{\circ} \mathrm{C}$ for $45 \mathrm{~s}$, and $72^{\circ} \mathrm{C}$ for & \\
\hline & & & & & $45 \mathrm{~s}$ for 30 cycles & \\
\hline & \multirow[t]{3}{*}{$v r n-B 1$} & Intr1/B/F & CAAGTGGAACGGTTAGGACA & Fu et al. (2005), & $95^{\circ} \mathrm{C}$ for $5 \mathrm{~min} ; 94^{\circ} \mathrm{C}$ for $60 \mathrm{~s}$ & 1160 \\
\hline & & Intr1/B/R4 & CAAATGAAAAGGAATGAGAGCA & Zhang et al. (2008) & $50^{\circ} \mathrm{C}$ for $120 \mathrm{~s}$, and $72^{\circ} \mathrm{C}$ for & \\
\hline & & & & & $180 \mathrm{~s}$ for 30 cycles & \\
\hline
\end{tabular}




\begin{tabular}{|c|c|c|c|c|c|c|}
\hline Locus & Allele & Marker name & Primer pair sequence $\left(5^{\prime} \rightarrow 3^{\prime}\right)$ & Reference & PCR conditions & $\begin{array}{l}\text { PCR product size } \\
\text { (bp) }\end{array}$ \\
\hline \multirow[t]{2}{*}{ Vrn-D1 } & $V r n-D I$ & $\begin{array}{l}\text { Intr1/D/F } \\
\text { Intr1/D/R3 }\end{array}$ & $\begin{array}{l}\text { GTTGTCTGCCTCATCAAATCC } \\
\text { GGTCACTGGTGGTCTGTGC }\end{array}$ & $\begin{array}{l}\text { Fu et al. (2005), } \\
\text { Zhang et al. (2008) }\end{array}$ & $\begin{array}{l}94^{\circ} \mathrm{C} \text { for } 2 \mathrm{~min} ; 95^{\circ} \mathrm{C} \text { for } 60 \mathrm{~s} ; \\
60^{\circ} \mathrm{C} \text { for } 60 \mathrm{~s} \text {, and } 72^{\circ} \mathrm{C} \text { for } \\
60 \mathrm{~s} \text { for } 40 \text { cycles }\end{array}$ & 1670 \\
\hline & $v r n-D 1$ & $\begin{array}{l}\text { Intr1/D/F } \\
\text { Intr1/D/R4 }\end{array}$ & $\begin{array}{l}\text { GTTGTCTGCCTCATCAAATCC } \\
\text { AAATGAAAAGGAACGAGAGCG }\end{array}$ & $\begin{array}{l}\text { Fu et al. (2005), } \\
\text { Zhang et al. (2008) }\end{array}$ & $\begin{array}{l}95^{\circ} \mathrm{C} \text { for } 3 \mathrm{~min} ; 94^{\circ} \mathrm{C} \text { for } 45 \mathrm{~s} \\
60^{\circ} \mathrm{C} \text { for } 60 \mathrm{~s} \text {, and } 72^{\circ} \mathrm{C} \text { for } \\
90 \mathrm{~s} \text { for } 30 \mathrm{cycles}\end{array}$ & 991 \\
\hline \multirow[t]{2}{*}{ Vrn-B3 } & $V r n-B 3$ & $\begin{array}{l}\text { VRN4-B-INS-F } \\
\text { VRN4-B-INS-R }\end{array}$ & $\begin{array}{l}\text { CATAATGCCAAGCCGGTGAGTAC } \\
\text { ATGTCTGCCAATTAGCTAGC }\end{array}$ & $\begin{array}{l}\text { Yan et al. (2006), } \\
\text { Zhang et al. (2008) }\end{array}$ & $\begin{array}{l}95^{\circ} \mathrm{C} \text { for } 3 \mathrm{~min} ; 94^{\circ} \mathrm{C} \text { for } 45 \mathrm{~s} ; \\
60^{\circ} \mathrm{C} \text { for } 60 \mathrm{~s} \text {, and } 72^{\circ} \mathrm{C} \text { for } \\
90 \mathrm{~s} \text { for } 30 \text { cycles }\end{array}$ & $\begin{array}{l}1200 \text { (Expected } \\
\text { PCR size) }\end{array}$ \\
\hline & $v r n-B 3$ & $\begin{array}{l}\text { VRN4-B-NOINS-F } \\
\text { VRN4-B-NOINS-R }\end{array}$ & $\begin{array}{l}\text { ATGCTTTCGCTTGCCATCC } \\
\text { CTATCCCTACCGGCCATTAG }\end{array}$ & $\begin{array}{l}\text { Yan et al. (2006), } \\
\text { Zhang et al. (2008) }\end{array}$ & $\begin{array}{l}95^{\circ} \mathrm{C} \text { for } 3 \mathrm{~min} ; 94^{\circ} \mathrm{C} \text { for } 45 \mathrm{~s} ; \\
60^{\circ} \mathrm{C} \text { for } 60 \mathrm{~s}, \text { and } 72^{\circ} \mathrm{C} \\
\text { for } 90 \mathrm{~s} \text { for } 30 \text { cycles }\end{array}$ & 1150 \\
\hline Ppd-D1 & Ppd-Dla & $\begin{array}{l}\text { Ppd-D1-F } \\
\text { Ppd-D1-R2 }\end{array}$ & $\begin{array}{l}\text { ACGCCTCCCACTACACTG } \\
\text { CACTGGTGGTAGCTGAGATT }\end{array}$ & $\begin{array}{l}\text { Beales et al. (2007), } \\
\text { Yang et al. (2008) }\end{array}$ & $\begin{array}{l}94^{\circ} \mathrm{C} \text { for } 2 \mathrm{~min} ; 94^{\circ} \mathrm{C} \text { for } 30 \mathrm{~s} ; \\
52^{\circ} \mathrm{C} \text { for } 30 \mathrm{~s} \text {, and } 72^{\circ} \mathrm{C} \\
\text { for } 60 \mathrm{~s} \text { for } 40 \text { cycles }\end{array}$ & 290 \\
\hline
\end{tabular}


None of the bread wheat cultivars or landraces gave any PCR product using the primer pair VRN4-B-INS-F - VRN4-B-INS-R, which demonstrated the lacking of the dominant $V r n-B 3$ allele. For $v r n-B 3$, a 1150 bp fragment was generated from 63 bread wheat cultivars and seven landraces using the primer pair VRN4-B-NOINS-F - VRN4-BNOINS-R, indicating presence of the recessive $v r n-B 3$ allele

\section{Discussion}

The productivity of wheat and their adaptation to climatic conditions are associated with their growth habits and heading dates, which are controlled to great extent by vernalization requirement and sensitivity to photoperiod. Vernalization and photoperiod genes play a significant role in the geographical adaptation, agronomic performance, quality and yield potential of wheat cultivars (Santra et al. 2009). Vernalization and photoperiod genes cause flowering and maturity time variations to escape drought or heat stresses during grain filling and damage from early frost in fall in some regions (Iqbal et al. 2007).

Different dominant $V r n$ and $P p d$ alleles in wheat were found to have different affects on vernalization requirement, flowering time and response to day length. Various reports have been published describing allelic variation of vernalization and photoperiod genes and, their effect on grain yield (Santra et al. 2005; Iqbal et al. 2007; Zhang et al. 2008; Yang et al. 2009). Stelmakh (1993) discovered that average grain yield per plant across environments was highest for spring wheat genotypes with $V r n-A 1$ or $V r n-B 1$, whereas cultivars with all three dominant alleles at homoeologous $V r n-1$ genes gave the lowest yield. Recently, Santra et al. (2009) concluded that if temperature and drought stress occurred during grain filling, the highest grain yield was reported for photoperiod insensitive wheat genotypes with the dominant allele at chromosome 5D (Vrn-D1), in combination with either $V r n-A 1$ or $V r n-B 1$. Therefore, optimizing the allelic composition at $V r n-1$ loci with photoperiod insensitivity may offer possibilities for developing wheat cultivars with higher yield potential and adaptation to a broader range of different climates.

Several physiological and morphological methods are available to detect vernalization and photoperiod genes in the background of wheat and other cereals, however, some of them are time consuming, labor intensive and influenced by environmental conditions, and thereby difficult to use in breeding programs. Recent advances in molecular genetics have facilitated the cloning of vernalization and photoperiod genes of wheat, which resulted in the development of gene and allele specific markers (diagnostic marker or functional markers) (Yan et al. 2004; Fu et al. 2005; Zhang et al. 2008). The development of diagnostic marker for $V r n-A 1, V r n-B 1, V r n-D 1$ and $P p d-D 1$ allows the detection of alleles of these genes in large wheat collections and is important for any wheat breeding programs.

In this study, sixty-three bread wheat cultivars and seven bread wheat landraces from Turkey were analyzed using eleven diagnostic primer combinations in order to identify the allelic status at four vernalization and one photoperiod genes. Our results revealed that $14 \%$ of Turkish wheat cultivars ( 8 cultivars) studied, carried dominant alleles for $\mathrm{Vrn}-\mathrm{Al}$, $52 \%$ (37) for $V r n-B 1$ and $27 \%$ (19) for $V r n-D 1$. The dominant $V r n-A l a$ allele was present 
in the genotypes Kırkpınar, Çukurova-86, Doğankent-1, Gönen-98, Tahirova-2000, Nurkent, Yüreğir and Așure, whereas the dominant allele $V r n-A 1 b$ was found in only 2 cultivars (Yayla and Ak-702). No Turkish wheat cultivar or landrace carried the Vrn-Alc allele. The Vrn-Ala frequency in Turkish bread wheat collection is much lower than in wheat collections when compared with different parts of the world. For instance, Fu et al. (2005) screened 117 spring wheat genotypes from Argentina and California and found that $V r n-A l a$ and $V r n-A l b$ were the predominant alleles, either alone or in combination with $V r n-B 1$ and $V r n-D 1$. The same authors and Iqbal et al. (2007) did not find any $V r n-A 1 c$ allele in their wheat varieties collections. Vrn-Ala was found only in the spring hexaploid wheat landraces from Afghanistan (Zhang et al. 2008). Iqbal et al. (2007) identified the $V r n-A 1 a$ allele in $85 \%$ of the Canadian spring wheat genotypes, $V r n-A 1 b$ in turn was found in only one genotype. Yan et al. (2004) reported that more than half of the spring wheat cultivars released between 1970-2004 in the USA and Argentina, carried the $V r n-A l a$ allele. The increase in the frequency of $V r n-A l a$ allele in spring wheat varieties in Argentina and USA might be related to the introduction of semi-dwarf germplasm from CIMMYT (International Wheat and Maize Improvement Center). We thought that the situation in Turkey could be similar; many wheat cultivars have been introduced from CIMMYT. However, we observed that only few cultivars introduced from CIMMYT carried the Vrn-Ala allele (Çukurova-86, Doğankent-1, Gönen-98, Yüreğir-89). Several other cultivars like Balatilla, Genç-99 and Adana-99 etc., were also introduced from CIMMYT (Yücel et al. 2009), but these genotypes did not carry the $V r n$-Ala allele. This is in contrast to the above-mentioned studies. $V r n-B 1$ is most frequent allele in bread wheat varieties from Turkey. Iqbal et al. (2007) reported that $50 \%$ of their lines carried the $V r n-B 1$ allele. However, the frequency of the dominant $V r n-B 1$ allele was less in Chinese cultivars (26\%) studied by Zhang et al. (2008). The dominant $V r n-B 3$ allele was not observed in our Turkish bread wheat collection. These finding are consistent with Zhang et al. (2008), that reported only two out of 278 cultivars from China carried the dominant $V r n-B 3$ allele. Vrn-D1 was the second most frequent allele (27\%) among the screened Turkish wheat varieties. This might be also due to the use of parental lines from CIMMYT germplasm. Yediay et al. (2010) reported that nearly all Turkish wheat cultivars in their study were bred directly and/or indirectly from CIMMYT germplasm. Eagles et al. (2009) reported that Vrn-D1 is the most frequent allele in Australian wheat cultivars developed from CIMMYT materials. This is also consistent with the situation in China (Zhang et al. 2008). Vrn-D1 was not found in any bread wheat landrace from Turkey, which is in contrast to the results of Iwaki et al. (2001) that reported Vrn-D1 is common in Indian bread wheat landraces.

Twenty-four bread wheat cultivars and one landrace carried recessive alleles at all four vernalization loci studied. Vrn-Ala was found in combination with the dominant $V r n-B 1$ allele in five bread wheat cultivars, namely Çukurova-86, Doğankent-1, Gönen-98, Nurkent and Yüreğir. The cultivars, Çukurova-86, Doğankent-1, Gönen-98, Nurkent and Yüreğir, carry both dominant vernalization alleles Vrn-Ala and $V r n-B 1$ in combination with Ppd-Dla. These cultivars were originated from CIMMYT parental lines. We observed that 11 cultivars contained both $V r n-B 1$ and $V r n-D 1$ alleles, and only the cultivar 
Doğankent-1 carried dominant alleles at three loci. Only one landrace 'Aśure' carried $V r n-A 1$ and $V r n-B 1$, which is not in agreement with other reports (Fu et al. 2005; Iqbal et al. 2007; Zhang et al. 2008; Santra et al. 2009). Iqbal et al. (2007) reported that the Vrn-B1 allele confers slight sensitivity to vernalization, resulting in slight delay of flowering. This allele was found in combination with the dominant $\mathrm{Vrn}$-Ala in 35\% of the Canadian lines. Genotypes carrying $V r n-B 1$ alone or in combination with $V r n-A 1$ showed early flowering and early maturing as compared to other combinations (Iqbal et al. 2007). Stelmakh (1993) reported that genotypes that carried the combinations of dominant alleles of $V r n-A 1$ with either $V r n-B 1$ or $V r n-D 1$ will flower early. This is associated with high yield of wheat in Ukraine. The majority of spring wheat germplasm carried the dominant allele $V r n-A 1 a$ alone or in combination with Vrn-B1, Vrn-D1 or Vrn-B3 alleles (Santra et al. 2009). Spring wheat cultivars carrying the $V r n-D 1$ allele in particular and/or in combination with other vernalization alleles, which causes normal flowering, may have the advantage for higher grain yield under a Mediterranean environment in Turkey. For instance, Ceyhan-99, Adana-99 and Golia carried both dominant Vrn-B1 and Vrn-D1 genes, which protect these cultivars against low temperature during January and February in the Mediterranean region of Turkey. Triple dominant genotypes have been reported to be early but low yielding. This is true for Doğankent, having three dominant alleles and low yield (Özkan et al. unpublished data). This cultivar suffers from cold damage in the Mediterranean region due to early flowering nature and ultimately results in lower yield. Genotypes having two dominant alleles in combination at two vernalization loci trend to mature early and exhibit higher yield potential (Iqbal et al. 2007). Similarly, Seri-82 carries Vrn-B1 and $V r n-D 1$. This cultivar has very high yield potential in the Mediterranean region with early flowering habit, which protects this cultivar from high temperature during grain filling. These examples suggest the possibility of combining specific dominant Vrn alleles in spring wheat cultivars to improve grain yield while maintaining their earliness.

The development of a diagnostic marker for the photoperiod insensitive allele of $P p d-D 1$ by Beales et al. (2007) allows its distribution to be determined across a wide range of germplasm. The photoperiod insensitive allele Ppd-D1a was found in $58.6 \%$ of cultivars and landraces in our wheat collection from Turkey. The frequency for this allele was higher in cultivars (60\%) compared with landraces (40\%) (Table 2). Recently, Zhang et al. (2010) tested 929 improved wheat cultivars and landraces from China and found that $P p d-D 1 a$ was present in $66 \%$ of wheat lines. Interestingly, the frequency of Ppd-Dla was higher in landraces than in modern cultivars. Foulkes et al. (2004) reported that currently most of the wheat varieties grown in Southern and Central Europe are photoperiod insensitive because of their wider adaptation. However, wheat varieties from the UK are mostly photoperiod sensitive.

The proportion of spring types with photoperiod insensitivity among the improved varieties is high, and at the same time, the proportion of spring types that carry $V r n-B 1$ or $V r n-D 1$ and Ppd-Dla has been increased in Turkey as well as in the world. This trend may be derived by global warming. Therefore, selection for growth habit has become a particularly critical wheat breeding aim. Appropriate molecular markers linked to Vrn-1 and 
Ppd-Dla genes can be used to accelerate the development of wheat cultivars showing wide adaptation with good yield potential for specific environments.

In Turkey, the majority of wheat is sown in autumn (in October and early November) such as in central and southeastern Anatolian region or early winter (in November and early December) as in Mediterranean region, and harvested in the following summer. Therefore these varieties should flower late enough to avoid frost damage but sufficiently early enough to mature before summer drought and high temperature occur. The photoperiod insensitive allele $P p d-D 1$ in combination with specific vernalization genes is required for different geographical regions. This would be highly desirable in Turkish wheat breeding programs. Based on our results presented here, Turkish wheat breeders can now modify the flowering time behavior suitable to a particular geographic region. This information will be helpful to wheat breeders trying to develop elite wheat cultivars carrying suitable vernalization and photoperiod alleles with higher grain yield potential and better quality suitable for different production environments through marker assisted selection.

\section{Acknowledgements}

We thank the TÜBİTAK (The Scientific and Technological Research Council of Turkey, TOVAG-1070207) and University of Çukurova (ZF2007YL28) for providing financial support for this work.

\section{References}

Beales, J., Turner, A., Griffiths, S., Snape, J.W., Laurie, D.A. 2007. A pseudo-response regulator is misexpressed in the photoperiod insensitive Ppd-Dla mutant of wheat (Triticum aestivum L.). Theor. Appl. Genet. 115:721-733.

Braun, H.J., Zincirci, N., Altay, F., Atli, A., Avci, M., Eser, V., Kambertay, M., Payne, T.S. 2001. Turkish wheat pool. In: Bonjean, A.P., Agnus, W.J. (eds), The World Wheat Book: A History of Wheat Breeding. Lavosier, Paris, France, pp. 851-879.

Distelfeld, A., Li, C., Dubcovsky, J. 2009. Regulation of flowering in temperate cereals. Curr. Op. Pl. Biol. 12:1-7.

Doyle, J.J., Doyle, J.L. 1987. A rapid DNA isolation procedure for small quantities of fresh leaf tissue. Phytochem. Bull. 19:11-15.

Dubcovsky, J., Lijavetzky, D., Appendino, L., Tranquilli, G. 1998. Comparative AFLP mapping of Triticum monococcum genes controlling vernalization requirement. Theor. Appl. Genet. 97:968-975.

Dyck, J.A., Matus-Cadiz, M.A., Hucl, P., Talbert, L., Hunt, T., Dubuc, J.P., Nass, H., Clayton, G., Dobb, J., Quick, J. 2004. Agronomic performance of hard red spring wheat isolines sensitive and insensitive to photoperiod. Crop Sci. 44:1976-1981.

Eagles, H.A., Cane, K., Vallance, N. 2009. The flow of alleles of important photoperiod and vernalization genes through Australian wheat. Crop Pasture Sci. 60:646-657.

Foulkes, M.J., Sylvester-Bradley, R., Worland, A.J., Snape, J.W. 2004. Effects of a photoperiod-response gene Ppd-D1 on yield potential and drought resistance in UK winter wheat. Euphytica 135:63-73.

Fu, D., Szücs, P., Yan, L., Helguera, M., Skinner, J.S., Von Zitzewitz, J., Hayes, P.M., Dubcovsky, J. 2005. Large deletion within the first in Vrn-1 are associated with spring growth habit in barley and wheat. Mol. Gen. Genet. 273:54-65.

Goncharov, N.P. 2003. Genetics of growth habit (spring vs. winter) in common wheat. Conformation of existence of dominant gene Vrn4. Theor. Appl. Genet. 107:768-772. 
Iqbal, M., Navabi, A., Yang, R., Salmon, D.F., Spaner, D. 2007. Molecular characterization of vernalization response gene in Canadian spring wheat. Genome 50:511-516.

Iwaki, K., Haruna, S., Niwa, T., Kato, K. 2001. Adaptation and ecological differentiation in wheat with special reference to geographical variation of growth habit and Vrn genotypes. Plant Breed. 120:107-114.

Kilian, B., Özkan, H., Pozzi, C., Salamini, F. 2009. Domestication of the Triticeae in the fertile crescent. In: Feuillet, C., Muehlbauer, G.J. (eds), Genetics and Genomics of the Triticeae. Plant Genetics and Genomics: Crops and Models 7. Springer Science+Business Media, LLC, New York, USA, pp. 81-119.

Ozkan, H., Brandolini, A., Pozzi, C., Effgen, S., Wunder, J., Salamini, F. 2005. A reconsideration of the domestication geography of tetraploid wheat. Theor. Appl. Genet. 110:1052-1060.

Santra, D.K., Santra, M., Allan, R.E., Campbell, K.G., Kidwell, K.K. 2009. Genetic and molecular characterization of vernalization genes $V r n-A 1, V r n-B 1$ and $V r n-D 1$ in spring wheat germplasm from Pacific Northwest region of USA. Plant Breed. 128:576-584.

Scarth, R., Law, C.N. 1984. The control of day length response in wheat by the group 2 chromosomes. Z. Pflanzenzücht. 92:140-150.

Stelmakh, A.F. 1993. Genetic effect of $V r n$ gene on heading date and agronomic traits in bread wheat. Euphytica 100:359-369.

Worland, A.J., Börner, A., Korzun, V., Li, M.W., Petrovic S., Sayers, E.J. 1998. The influence of photoperiod genes on the adaptability of European winter wheat. Euphytica 100:385-394.

Yan, L., Helguera, M., Kato, K., Fukuyama, S., Sherman, J., Dubcovsky, J. 2004. Allelic variations at VRN-1 promoter in polyploidy wheat. Theor. Appl. Genet. 109:1677-1686.

Yan, L., Loukojanov, A., Tranquillo, G., Helguera, M., Fahima, T., Dubcovsky, J. 2003. Positional cloning of vernalization gene VRN1. Proc. Natl. Acad. Sci. USA. 100:6263-6268.

Yang, F.P., Zhang, X.K., Xia, X.C., Laurie, D.A., Yang, W.X., He, Z.H. 2009. Distribution of photoperiod insensitive Ppd-Dla allele in Chinese wheat cultivars. Euphytica 165:445-452.

Yediay, F.E., Baloch, F.S., Kilian, B., Özkan, H. 2010. Testing of rye specific markers located on 1RS chromosome and distribution of 1AL.RS and 1BL.RS. translocations in Turkish wheat (Triticum aestivum L., Triticum durum Desf.) varieties and landraces. Genet. Resour. Crop. Evol. 57:119-129.

Yücel, C., Baloch, F.S., Özkan, H. 2009. Genetic analysis of some physical properties of bread wheat grain (Triticum aestivum L.). Turkish J. of Agriculture and Forestry 33:525-535.

Zhang, X.K., Xia, X.C., Xiao, Y.G., Dubcovsky, J., He, Z.H. 2008. Allelic variation at vernalization genes $V r n-A 1, V r n-B 1, V r n-D 1$ and $V r n-B 3$ in Chinese common wheat cultivars and their association with growth habit. Crop Sci. 48:458-470.

Zhang, Y., Liu, W.C., Li, J., Wei, H.T., Hu, X.R., Li, Y.J., Lu, B.R., Yang, W.Y. 2010. Distribution and selective effects of $V r n-A 1, V r n-B 1$, and $V r n-D 1$ genes in derivative varieties from four cornerstone breeding parents of wheat in China. Agricultural Sci. in China 9:1389-1399.

Cereal Research Communications 39, 2011 